\title{
Evaluation of Post-operative Pain after Irrigation Using End-vented NaviTip Tips versus Vibringe Sonic Irrigating System in Teeth with Acute Pulpitis with Apical Periodontitis: A Randomized Clinical Trial
}

\author{
Mohamed Elsaeed Mohamed Ali $^{1 *}$, A. Magdy ${ }^{2}$, W. Hussien ${ }^{3}$ \\ ${ }^{1}$ Department of Endodontics, Cairo University, Giza, Egypt; ${ }^{2}$ Department of Endodontics, Faculty of Oral and Dental Medicine, \\ Beni Suef University, Beni Suef, Egypt; ${ }^{3}$ Department of Endodontics, Faculty of Oral and Dental Medicine, El-Azhar University \\ (Girls), Cairo, Egypt
}

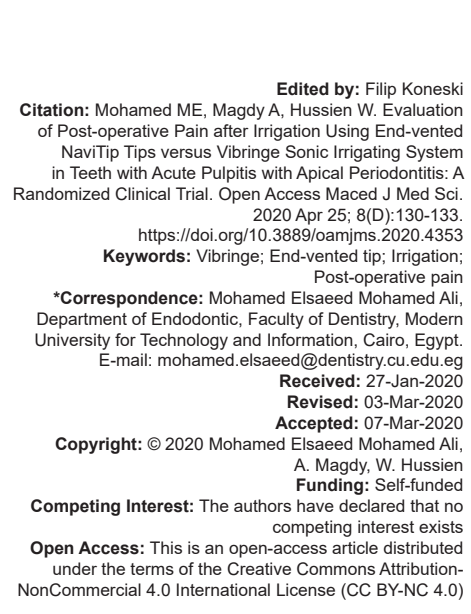

\section{Introduction}

Post-operative pain is defined as the sensation of discomfort after endodontic intervention and is reported by $25-40 \%$ of patients irrespective of pulp and periradicular status. According to the 2011 systematic review of Pak and White, the prevalence of pain in the first $24 \mathrm{~h}$ is $40 \%$, falling to $11 \%$ after 7 days. Dentinal debris, pulp tissue, microorganisms, and irrigants can be conveyed to the periradicular tissues during root canal preparation and such extrusion of debris can lead to post-operative complications, such as flare-ups.

For better cleaning and shaping of the root canal system, many irrigating solutions are mostly used during mechanical preparation and as final rinse to overcome the use of a single irrigant, such as sodium hypochlorite $(\mathrm{NaOCl})$, chlorhexidine (chx), or ethylenediaminetetraacetic acid (EDTA). In addition to these irrigants, many irrigation devices and needle tips have been introduced to deliver the irrigant throughout the root canal using sonic or ultrasonic energy and negative apical pressure.

Vibringe is a pioneer in root canal sonic irrigation that helps in activation of irrigate solutions in the root canal system, only in one step. The activation by acoustic streaming helps in completes the irrigation procedure and raises the success rate of root canal treatments. It was noticed that the Vibringe system significantly gives high quality of debridement. It helps in removal of smear layer from inside the root canal.

\section{Materials and Methods}

The trial design of this study is a parallel randomized controlled trial (RCT). In this study we take the approval of the Ethics Committee of Faculty of Oral and Dental Medicine, Maina University, Egypt. 


\section{Sample size determination}

Sample size was calculated using PS program, with standard deviation 30 . We needed to study 17 experimental subjects and 17 control subjects to be able to reject the null hypothesis that the population means of the experimental and control groups are equal with probability (power) 0.8 . The Type I error probability associated with this test of this null hypothesis is 0.05 . With the dropout rate of $10 \%$, the total sample size becomes 38 .

\section{Patient selection}

Thirty-eight volunteer patients fitting the inclusion criteria described later were included in the study. The study participants were recruited from the pool of patients in the Department of Endodontics, Maina University, Egypt.

\section{Eligibility criteria}

Inclusion criteria

The following criteria were included in the study:

1. Healthy persons between the age group of 18 and 65 years.

2. Posterior teeth that were diagnosed with irreversible pulpitis and confirmed using periapical radiographs.

\section{Exclusion criteria}

The following criteria were excluded from the study:

1. Patients using pre-operative drugs that can alter pain perception as anti-inflammatory, analgesic, or antibiotics in the past $24 \mathrm{~h}$.

2. Pregnant patients or allergic patients to used materials.

3. Teeth with necrotic pulp, periapical radiolucency, swelling, or sinus tract.

4. Teeth requiring retreatment.

5. Teeth with Grade 2 or 3 mobility.

\section{Treatment procedure}

Before the treatment, a careful medical and dental history was taken. Pre-operative data for each patient were recorded in the predesigned patient's chart which includes age, sex, tooth number, and intensity of pain before the treatment. The severity of pain was measured using the Numerical Rating Scale (NRS). According to this scale, the level of pain was documented in the range of 0-10 numerically and verbally as no pain (0), mild pain (1-3), moderate pain (4-6), and severe pain (7-10). The treatment and the study design were explained to the qualifying patients and informed consent was obtained from the voluntary patients who were willing to participate in the study.

\section{Randomization}

Random sequence was generated using the random function in Microsoft Excel software. Allocation concealment was phone based. The random sequence tables were kept with the assistant supervisor. The operator called the assistant supervisor for confirmation of eligibility and to assign the patient to a group according to the random sequence.

\section{Endodontic protocol}

All the treatments were carried out by a single operator. Each patient was given a pain scale chart (NRS) to record his/her pain level before any endodontic treatment. Each patient was anaesthetized using 3\% mepivacaine $\mathrm{HCl}$ (ALEX CO., Egypt). Access to pulp chamber was performed using a small round bur and completed using Endo-Z Bur. The tooth was properly isolated with rubber dam.

Working length was determined using an electronic apex locator then confirmed with intraoral periapical radiograph, to be $0.5-1 \mathrm{~mm}$, shorter than radiographic apex. Mechanical preparation of root canals was done by crown-down technique using ProTaper Universal rotary instruments, according to the manufacturer instructions.

Patients were randomly divided into two groups according to techniques of irrigation used during irrigation: Group A: Vibringe sonic irrigating syringe with NaviTip ${ }^{\circledR}$ 29-gauge $27 \mathrm{~mm}$ with endvented NaviTipTip and Group B: Conventional needle with NaviTip ${ }^{\circledR}$ 29-gauge $27 \mathrm{~mm}$ with end-vented NaviTipTip.

For both groups, $2 \mathrm{ml}$ of $2.5 \% \mathrm{NaOCl}$ was expressed over $30 \mathrm{~s}$ after every use of each rotary instrument. As a final flush, $3 \mathrm{ml}$ of $17 \%$ EDTA was used for $1 \mathrm{~min}$ to remove the smear layer followed by $10 \mathrm{ml}$ of distilled water.

The canals obturated in the next. The patients were instructed to mark pain level at the pain chart. After the treatment, all patients received one capsule of placebo and prescribed tablets of $200 \mathrm{mg}$ ibuprofen with the instructions to take the placebo within the $0-4 \mathrm{~h}$ time interval after the treatment if needed, then only one tablet of analgesic every $8 \mathrm{~h}$ in the event of pain after calling the doctor for consultation and to record the number of tablets needed. 


\section{Results}

\section{Demographic data}

The mean age of patients in Group A was 32.7 \pm 7.8 years and range 18-45 while in Group B was 31.2 \pm 7.7 years and range $22-55$. There was no significant difference between mean age values between both groups ( $p=0.547)$.

Gender distribution in Group A involved 11 males and 8 females while in Group B involved 7 males and 12 females. There was no significant difference between both groups for gender $(p=0.194)$.

In Group A, $47.4 \%$ of the patients received endodontic treatment for the mandibular premolars and $52.9 \%$ for the mandibular molars while in Group B. About $42.1 \%$ of the patients received endodontic treatment for the mandibular premolars and $57.9 \%$ for the mandibular molars. There was no significant difference between both groups for the treated tooth type at $p=0.744$.

Table 1: Median and range of NRS score at different time points in the tested groups by Mann-Whitney and overtime in each group by Friedman test

\begin{tabular}{|c|c|c|c|c|c|c|c|}
\hline \multirow[t]{2}{*}{ Groups different times } & \multicolumn{3}{|c|}{$\begin{array}{l}\text { Group A (irrigation with } \\
\text { Vibringe and } \\
\text { end-vented needle) }\end{array}$} & \multicolumn{3}{|c|}{$\begin{array}{l}\text { Group B (irrigation with } \\
\text { con. syringe and } \\
\text { end-vented needle) }\end{array}$} & \multirow[t]{2}{*}{$p$ value 1} \\
\hline & Median & Min. & Max. & Median & Min. & Max & \\
\hline Pre-operative pain & 8 & 0 & 10 & 7 & 3 & 10 & 0.756 \\
\hline Immediate post-operative & 3 & 0 & 7 & 2 & 0 & 7 & 0.343 \\
\hline $4 \mathrm{~h}$ & 3 & 0 & 10 & 3 & 0 & 8 & 0.687 \\
\hline $12 \mathrm{~h}$ & 3 & 0 & 10 & 3 & 0 & 8 & 0.687 \\
\hline $24 \mathrm{~h}$ & 3 & 0 & 5 & 3 & 0 & 6 & 0.892 \\
\hline $48 \mathrm{~h}$ & 2 & 0 & 7 & 1 & 0 & 6 & 0.601 \\
\hline $72 \mathrm{~h}$ & 0 & 0 & 9 & 1 & 0 & 4 & 0.899 \\
\hline 7 days & 0 & 0 & 4 & 0 & 0 & 4 & 0.784 \\
\hline$p$ value 2 & $<0.001$ & & & $<0.001$ & & & \\
\hline
\end{tabular}

\section{Pain intensity (NRS scores)}

Results showed that there was no statistically difference between the two groups regarding prevalence of pre-operative pain, after $4 \mathrm{~h}, 12 \mathrm{~h}, 24 \mathrm{~h}$, and $48 \mathrm{~h}$ and 7 days, as shown in Table 1 and Figure 1.

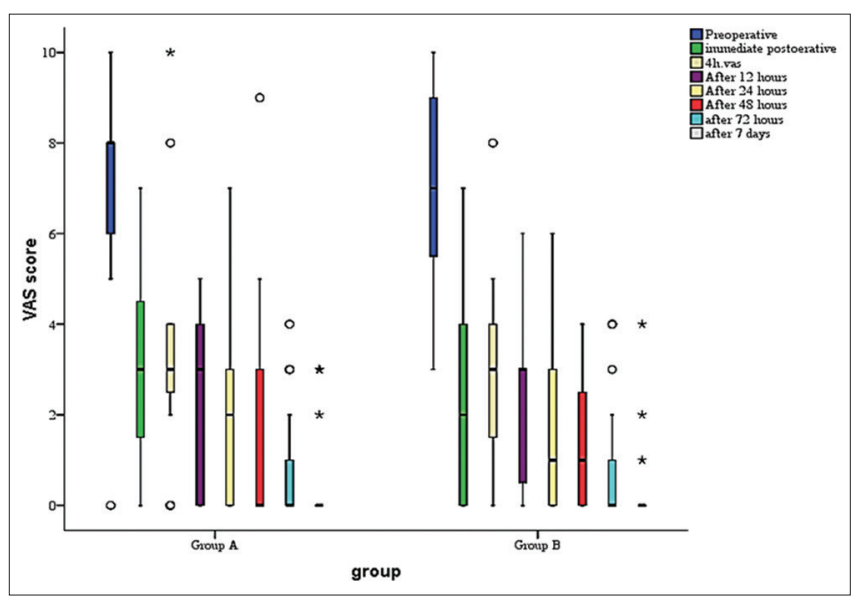

Figure 1: Box plot showing the median numerical rating scale score in the tested groups at different time points. Two groups (Group A: Irrigation with Vibringe sonic irrigating syringe with end-vented NaviTip. Group B: Irrigation conventional syringe with end-vented NaviTip)

\section{Drug intake}

Patients take placebo

In Group A, $68.4 \%$ of the patients received placebo, while in Group B, 68.4\% of the patients received placebo, there was no significant difference the two groups $(p=1.000)$.

\section{ibuprofen)}

\section{Patients received the medication (200 mg}

In Group A, $84.2 \%$ of the patients received the medication (200 mg ibuprofen), while in Group B, $61.1 \%$ of the patients received the medication $(200 \mathrm{mg}$ ibuprofen), there was no significant difference between the two groups $(p=0.114)$.

\section{Discussion}

The purpose of this randomized controlled clinical study was to compare the difference in postoperative pain after using Vibringe syringe with endvented and conventional syringe with end-vented tip needle. Mild discomfort after root canal treatment is a common experience for patients [1]. It is very difficult to differentiate which factor causes pain and it is difficult to determine whether single or multiple factor elicit pain. In the present study, only mandibular premolars and molars were selected [2], [3].

In the present study, $2.5 \%$ of $\mathrm{NaOCl}$ was used as intracanal irrigant; this concentration of $\mathrm{NaOCl}$ is in accordance with Gomes-Filho et al. [4] who reported a good biocompatibility [4]

Banos et al. [5] reported that NRS is a reliable method to assess pain in clinical settings when compared to the verbal rating scale. In this study, NRS was used for the evaluation of pain, because it is visually and verbally quantified for a better understanding by the patients.

In this study, Vibringe system and conventional syringe with both end-vented NaviTip showed that an observable drop in pain level was recorded immediately post-operative, 4 h, 12 h, 24 h, 48 h, and $72 \mathrm{~h}$ and 7 days postoperatively until disappeared. This is in accordance with the previous studies that demonstrated that the incidence of post-obturation pain decreased overtime; it was greatest during the first $48 \mathrm{~h}$, with a steady reduction in the following 7 days [6], [7], [8].

Results showed no significance difference between the two groups in post-operative pain. This was in contrary to Ramamoorthi et al. [9] who showed EndoActivator resulted in significantly less 
post-operative pain than conventional syringe with 27 gauge open end needle. This may be attributed to the activation of the irrigants done by EndoActivator. Moreover, Mtwo rotary files were used while in the present study, Universal ProTaper rotary file was used in the mechanical preparation.

Our results also were in contrary to Al-Zaka [10] who showed that the safety irrigator showed significantly less post-operative pain than subsonic EndoActivator and conventional needle irrigation. This may attributed to the safety irrigator which is an irrigation/evacuation system that apically delivers the irrigant under positive pressure through a thin needle containing a lateral opening and evacuates the solution through a large needle at the root canal orifice. Furthermore, the type of teeth selected in this study was the anterior teeth while in the present study, the posterior teeth were selected.

As the previous studies show, factors such as age, sex, pulpal status, allergies, and pre-operative pain play a significant role in post-operative pain [11]. In this study, there were no significant differences for gender, age distribution, and baseline pain score between the two groups; therefore, the effects of these variables were considered to be minimized.

\section{Conclusions}

Within the limitations of this study, it could be concluded that:

There is no statistical significance difference between Vibringe sonic irrigating syringe with endvented needle and conventional syringe with end-vented NaviTip, while in both groups, there was a statistically significant decrease in pain intensity preoperatively compared with all other time periods.

\section{Ethical Clearance}

This study was approved by the Ethics Committee of the Faculty of Dentistry, Minia University.

\section{References}

1. Sathorn C,ParashosP, MesserH. The prevalence of postoperative pain and flare-up in single-and multiple-visit endodontic treatment: A systematic review. Int Endod J. 2008;41(2):91-9. https://doi.org/10.1111/j.1365-2591.2007.01316.x

PMid:17956561

2. Martin-Gonzalez J, Echevarria-Perez M, Sanchez-Dominguez B Tarilonte-Delgado ML, Castellanos-Cosano L, Lopez-Frias FJ, et al. Influence of root canal instrumentation and obturation techniques on intra-operative pain during endodontic therapy. Med Oral Patol Oral Cir Bucal. 2012;17(5):912-8. https://doi.org/10.4317/medoral.18234 PMid:22549694

3. Yesilsoy C, Koren LZ, Morse DR, Rankow H, Bolanos OR Furst ML. Post-endodontic obturation pain: A comparative evaluation. Quintessence Int. 1988;19(6):431-8. PMid:3269592

4. Gomes-filho JE, Aurelio KG. Comparison of the biocompatibility of different root canal irrigants. J Appl Oral Sci. 2008;16(2):13744. https://doi.org/10.1590/s1678-77572008000200011 PMid:19089206

5. Banos JE, Bosch F, Canellas M, Bassols A, Ortega F, Bigorra J Acceptability of visual analogue scales in the clinical setting: A comparison with verbal rating scales in postoperative pain. Methods Find Exp Clin Pharmacol. 1989;11(2):123-7.

PMid:2709918

6. Genet JM, WesselinkPR, Thoden SK. The incidence of postoperative pain in endodontic therapy. Int Endod J. 1986;19(5):221-9. https:// doi.org/10.1111/j.1365-2591.1986.tb00482.x

PMid:3473042

7. Yoldas O, Topuz A, Isci AS, Oztunc H. Postoperative pain after endodontic retreatment-single versus two-visit treatment. Oral Surg Oral Med Oral Pathol Oral Radiol Endod. 2004;98(4):4837. https://doi.org/10.1016/j.tripleo.2004.03.009 PMid:15472665

8. Al-Negrish AR, Habahbed R. Flare up rate related to root canal treatment of asymptomatic pulpally necrotic central incisor teeth in patients attending a maxillary hospital. J Dent. 2006;34(9):635-40. https://doi.org/10.1016/j.jdent.2005.12.007 PMid: 16439046

9. Ramamoorthi S, Nivedhitha MS, Divyanand MJ. Comparative evaluation of postoperative pain after using endodontic needle and endo activator during root canal irrigation: A randomised controlled trial. Aust Endod J. 2015;41(2):78-87. https://doi. org/10.1111/aej.12076 PMid:25195661

10. Al-Zaka IM. The incidence of pain after root canal treatment using different irrigation methods. Tikrit J Dent Sci. 2012;1:38-43.

11. Wang C, Xu P, Ren L, Dong G, Ye L. Comparison of postobturation pain experience following one-visit and two-visit root canal treatment on teeth with vital pulps: A randomized controlled trial. Int Endod J. 2010;43(8):692. https://doi. org/10.1111/j.1365-2591.2010.01748.x

PMid:20491987 